\title{
Influence of common health disorders on the length of productive life and stayability in German Holstein cows
}

\author{
T. Shabalina, T. Yin, and S. König* (1) \\ Institute of Animal Breeding and Genetics, Justus-Liebig-University of Giessen, Germany 35390
}

\begin{abstract}
The aim of this study was to infer phenotypic and genetic effects of health disorders on longevity traits, considering Holstein dairy cow records from large-scale co-operator herds. In this regard, we focused on 13 different disease traits and on 2 longevity definitions: length of productive life (LPL) and stayability (STAY). The LPL was defined as the interval in days from first calving to culling. For LPL, we considered 90,215 cows with known culling dates. For binary STAY, we defined 3 survival stages in the first 3 lactations: from calving to DIM 59, from DIM 60 to DIM 299, and from DIM 300 to the next calving date. Due to the earlier trait recording possibilities, 129,386 cows were considered for the STAY analysis. Accordingly, the presence or absence of diseases in lactation stages were defined as binary traits. A further data set for the 90,215 cows with a culling date included the subjective culling reasons defined by farmers. Comparison of culling reasons, as defined by farmers, with diagnoses from the disease data set indicated some disagreements. For example, only $18.71 \%$ of the cows with the farmer culling reason "metabolic diseases" were diagnosed with a metabolic disorder. Better agreements were identified for mastitis (84.09\%). Phenotypically, in most cases, occurrence of diseases at different lactation stages had negative influence on LPL and STAY. In this regard, we identified strong detrimental effects of clinical mastitis and of metabolic disorders from early lactation stages on longevity traits. For example, the presence of clinical mastitis in the first stage of first lactation was associated with LPL decrease of $95.35 \mathrm{~d}$. Using generalized linear mixed models for binary health disorders, heritabilities ranged from $<0.01$ ( \pm 0.079 standard error) for ruminal acidosis early in first, second, and third lactation to $0.24( \pm 0.039)$ for interdigital hyperplasia from the last stage in third lactation. Heritabilities from single-trait and bivariate animal models ranged
\end{abstract}

Received May 18, 2019.

Accepted September 11, 2019.

*Corresponding author: sven.koenig@agrar.uni-giessen.de from $0.03( \pm 0.003)$ to $0.10( \pm 0.007)$ for LPL, and from $0.01( \pm 0.002)$ to $0.06( \pm 0.007)$ for STAY. Genetic correlations between longevity traits and health disorders were mostly negative (i.e., favorable in a breeding sense). For improvements to longevity genetic evaluations for young bulls with a limited number of daughter culling dates, we suggest consideration of health traits from a well-organized co-operator herd monitoring system as early longevity predictors, especially for censored data. Genetic correlations between mastitis from different lactation stages with LPL and STAY ranged from $-0.28( \pm 0.07)$ to $-0.69( \pm 0.05)$, and from -0.26 $( \pm 0.08)$ to $-0.77( \pm 0.08)$, respectively. Interestingly, only diagnoses for dermatitis digitalis showed opposite results phenotypically and genetically. Strong genetic associations between ruminal acidosis and STAY were observed (genetic correlations: $-0.48 \pm 0.18$ to $-0.98 \pm$ 0.31 ), supporting the inferred phenotypic associations. Genetic correlations between longevity traits LPL and STAY were quite large, between $0.77( \pm 0.11)$ and 0.94 $( \pm 0.02)$ for the different lactation stages, suggesting utility of early STAY information when attempting genetic improvements for longevity.

Key words: longevity, subjective culling reason, health disorder, genetic parameter

\section{INTRODUCTION}

Longevity, as an economically important trait, is included in overall dairy cattle breeding goals in many countries (Interbull, 2016). In most genetic evaluations, longevity is defined as the length of productive life (LPL), reflecting the period from first calving to date of culling. However, in genetic evaluations for LPL, data sets with culling dates for a large number of daughters are only available for old bulls. Hence, most LPL daughter records reflect a censored data structure. In consequence, it is imperative to identify proper early indicator traits, to improve the accuracy of genetic longevity evaluations. Several studies have identified strong influences of linear type traits (Buenger et al., 2001) or of SCS (Pritchard et al., 2013b) on LPL. However, type traits and SCS are only indicators for cow health. 
In this regard, Egger-Danner et al. (2015) highlighted the possible improvements in genetic evaluations when directly considering diagnoses for cow health. In further consequence, we suggest consideration of direct health traits as indicators in genetic evaluations for longevity. Such an attempt requires health disorder data sets from routinely recording systems, at best on a populationwide level. Population-wide recording of health traits was initiated in Scandinavia in 1978 (Philipsson and Lindhé, 2003) and recently has been established in other countries (Stock et al., 2013). As an alternative, instead of implementing population-wide recording, some German breeding organizations focus on health trait recording in a smaller sample of so-called co-operator herds. In such large-scale herds, cows are genotyped and phenotyped for a broad pattern of novel functional traits, which is a unique data pool when setting up cow training sets for genomic selection (Klein et al., 2019).

A further trait definition reflecting longevity considers the probability of survival at specific lactation stages. This binary trait definition is known as stayability (STAY). In Germany, since April 2018, STAY has officially been introduced in national genetic evaluations, considering different periods from first to fourth calving (VIT, 2018). Compared with LPL, STAY provides longevity information at earlier age stages, such as, first, for cows surviving the early lactation period. Furthermore, the STAY definition allows consideration of cows without culling dates - that is, cows surviving the last defined lactation stage. However, genetic correlations lower than 0.8 between STAY from different lactation stages (Wiebelitz et al., 2014; Heise et al., 2016) indicate alterations of the genetic background with aging. Accordingly, correlations between EBV for different STAY periods, or between EBV of SCS from the respective periods, were only in a moderate range (Heise et al., 2016). Hence, the changing genetic background for STAY as well as for a STAY indicator trait (e.g., SCS, mastitis) indicate variations of genetic covariances between the trait categories longevity and health.

Further information related to cow health and cow longevity are cow culling reasons. Culling reasons are entries in a population-wide database system (ADR, 2017), but they reflect subjective appraisals by the herd owner. A disadvantage of this recording scheme is that some cows might have several culling reasons, but only 1 specific reason is considered in the database. Nevertheless, Heise et al. (2018) genetically analyzed cow culling reason and indicated the potential to improve genetic evaluations, as for cow health. As an alternative, we suggest strong consideration of veterinarian disease diagnoses from German co-operator herds. A co-operator herd system implies close collaborations between breeding organizations and veterinarian institutions, as with regard to implementation of systematic health monitoring. König et al. (2008a) emphasized the high data quality from German co-operator herds, due to estimates for intraherd genetic parameters.

The aim of the present study was to use comprehensive health and longevity data sets from co-operator herd cows for (1) the evaluation of culling reason data quality, (2) association analyses between health disorders with longevity traits LPL and STAY phenotypically and genetically, and (3) genetic correlation estimations between STAY and LPL.

\section{MATERIALS AND METHODS}

\section{Data}

Trait recording was accomplished in 57 large-scale co-operator herds located in the German federal states of Mecklenburg-Vorpommern and Berlin-Brandenburg. In total, data sets for longevity, test-day production, and health traits were available from 129,386 Holstein cows. Previous to our analyses, we excluded 15,326 cows that were sold for export. First calving years of the cows spanned the period from 2004 to 2017. Ages at first calving ranged between 18 and 42 mo. All cows had at least one official test-day observation within the first 100 DIM of the first, second, or third lactation (L1, L2, and L3, respectively). The pedigree file considered 277,341 animals. Cows with records could be traced back at least 3 generations. The oldest founder animals were born in 1940 .

Longevity. For longevity evaluations, we focused on the 2 trait definitions LPL and STAY. The LPL was defined as the productive period from the first calving date until the culling date. The average LPL for the 90,215 cows with a culling date was $977.10( \pm 626.77$ SE) days. Following the method of Heise et al. (2016), we created 3 different stages within lactations: early lactation, from calving to DIM 59; middle lactation, DIM 60 to 299; and late lactation, including the dry period, from DIM 300 to the next calving date. Thus, the third stage had variable lengths. For all 3 lactations, the considered 3 lactation stages were named as L1.1, L1.2, and L1.3 in the first lactation, L2.1, L2.2, and L2.3 in the second, and L3.1, L3.2, and L3.3 in the third. Regarding STAY, a cow was coded as 1 when she was alive at the end of a stage; otherwise, for a culling date within the stage, a code 0 was assigned. For example, if a cow was culled at DIM 61 in L1, the STAY code for the stage L1.1 was 1 , but the cow would be coded 0 for the following lactation stages. 
Table 1. Disease incidences (\%) in different lactation stages within lactations 1, 2, and 3 for cows from co-operator herds ${ }^{1}$

\begin{tabular}{|c|c|c|c|c|c|c|c|c|c|c|c|c|}
\hline Disease $^{2}$ & \multicolumn{4}{|c|}{ Lactation 1} & \multicolumn{4}{|c|}{ Lactation 2} & \multicolumn{4}{|c|}{ Lactation 3} \\
\hline MAST & 14.90 & 14.04 & 5.69 & 28.06 & 14.70 & 25.03 & 7.75 & 35.69 & 18.44 & 29.00 & 8.97 & 40.33 \\
\hline DD & 3.45 & 10.71 & 5.29 & 15.03 & 4.13 & 10.23 & 4.91 & 14.46 & 4.04 & 9.19 & 3.97 & 12.82 \\
\hline WLD & 0.33 & 1.25 & 0.67 & 1.90 & 0.51 & 2.02 & 1.21 & 2.95 & 0.95 & 3.31 & 1.94 & 4.71 \\
\hline HYP & 0.51 & 1.41 & 0.88 & 2.27 & 1.11 & 2.33 & 1.22 & 3.59 & 1.53 & 2.89 & 1.35 & 4.32 \\
\hline MFEV & & & & & 1.17 & & & & 4.46 & & & \\
\hline ENDO & 19.59 & 5.38 & & 22.93 & 17.92 & 6.31 & & 21.77 & 20.76 & 6.94 & & 24.60 \\
\hline OCD & & 20.71 & & & & 21.66 & & & & 22.59 & & \\
\hline CYST & & 6.24 & & & & 8.20 & & & & 8.79 & & \\
\hline CLP & & 2.65 & & & & 3.19 & & & & 3.35 & & \\
\hline $\mathrm{RP}$ & 6.52 & & & & 8.38 & & & & 10.60 & & & \\
\hline
\end{tabular}

${ }^{1}$ Empty cells $=$ no relevance of the disease in the respective lactation stage, as explained in the manuscript text.

${ }^{2} \mathrm{MAST}=$ clinical mastitis; $\mathrm{SU}=$ sole ulcer; $\mathrm{DD}=$ digital dermatitis; $\mathrm{WLD}=$ white line disease HYP $=$ interdigital hyperplasia; $\mathrm{ACID}=$ ruminal acidosis; KET = ketosis; MFEV = milk fever; ENDO = endometritis; OCD = ovarian cycle disorder; CYST $=$ ovarian cysts; CLP $=$ corpus luteum persistens; $\mathrm{RP}=$ retained placenta.

${ }^{2}$ Lact. $=$ lactation disease incidence.

Consequently, our STAY definition implied 9 binary traits for all cows. For STAY, the analyses additionally considered cows without a culling date after the last stage (129,386 cows for the STAY analyses).

Health Disorders. For the recording of health disorders, veterinarians and herd managers used the hierarchical diagnosis key developed by Feucker and Staufenbiel (2003). The same diagnosis key is also used in the official guidelines of the International Committee for Animal Recording (ICAR; Stock et al., 2013). Official health trait recording was initiated in January 2008. In the present study, the cows from the longevity data set had health records for the period from January 2008 until January 2017. We considered 13 specific diseases from the overall disease categories of udder, claw, metabolism, and female fertility. These diseases are veterinarian diagnoses from the selected co-operator herds, with continuous entries over the whole recording period. The 13 diseases were clinical mastitis (MAST) from the udder health category; sole ulceration (SU), digital dermatitis (DD), white line disease (WLD), and interdigital hyperplasia (HYP) from the claw disorder category; acidosis (ACID), ketosis (KET), and milk fever (MFEV) for metabolism; and ovarian cycle disorders (OCD), endometritis (ENDO), ovarian cysts (CYST), corpus luteum persistens (CLP), and retained placenta $(\mathbf{R P})$ for female fertility disorders. For at least one entry in the lactation stage, the respective disease was scored 1 (diseased); otherwise a score of 0 (healthy) was assigned. Consideration of the same lactation stages as used for the STAY definition implied 9 binary traits for each disease. In addition to lactation stage disease incidences, we calculated lactation disease incidences. At least one disease entry during lactation implied a score of 1 for the respective disease; otherwise, a score of 0 was assigned. Incidences for the 13 diseases for the different lactation stages and lactations are given in Table 1.

Culling Reasons. The official scheme for cow culling reasons considers disposals due to udder diseases, infertility, claw disorders, metabolic diseases, other diseases, low milk yield, poor milkability, age, selling for breeding, and other problems. The cow culling reason database reflecting the answers of farmers only considers 1 culling reason per cow. The culling reason frequencies considering all cows (apart from the cows sold for breeding in other regions) were $24.21 \%$ due to udder diseases, $21.72 \%$ due to infertility, $16.97 \%$ due to claw disorders, $12.84 \%$ due to metabolic diseases, $7.57 \%$ due to low milk yield, $4.82 \%$ due to poor milkability, $0.16 \%$ due to age, and $5.81 \%$ due to other problems. We compared the health-related culling reasons with the disease entries from the health database.

\section{Statistical Models}

Phenotypic Effects of Diseases on Longevity. Linear models were applied to test the effects of each disease from the different lactation stages on Gaussiandistributed LPL in consecutive runs. We used the $l m$ function in R (R Development Core Team, 2017). Model [1] was as follows:

$$
\begin{aligned}
& y_{i j k l m n o p}=\mu+\Delta \mathrm{M}_{i}+D I M_{j}+H_{k}+J_{l}+S_{m}+F C A_{n} \\
& +H S_{o}+e_{i j k l m n o p},
\end{aligned}
$$


where $y_{i j k l m n o p}=\mathrm{LPL}$ (in days) $; \mu=$ overall mean; $\Delta \mathrm{M}_{i}$ $=$ linear regression for the difference between the first test-day milk yield and the herd average; $D I M_{j}=$ linear regression for days in milk; $H_{k}=$ fixed herd effect; $J_{l}=$ fixed effect of calving year; $S_{m}=$ fixed effect of calving season (Jan. through Apr., May through Sep., or Oct. through Dec.); $F C A_{n}=$ fixed effect for age at first calving (classes 20 to 23,24 to 26,27 to 29 , or $>29$ mo); $H S_{o}=$ fixed effect for the health status of the respective health disorder $(0=$ healthy, $1=$ diseased $)$; and $e_{i j k l m n o p}$ $=$ random residual error.

Binary STAY was analyzed via generalized linear models, applying the $g l m$ function in $\mathrm{R}$ ( $\mathrm{R}$ Development Core Team, 2017). For this, we used a logit link function. Statistical Model [2] was as follows:

$$
\begin{aligned}
& \operatorname{logit}\left(\pi_{i j k l m n o}\right)=\log \left(\frac{\pi_{i j k l m n o}}{1-\pi_{i j k l m n o}}\right)=\mu+\Delta \mathrm{M}_{i}+D I M_{j} \\
& +H_{k}+J_{l}+S_{m}+F C A_{n}+H S_{o},
\end{aligned}
$$

where $\pi_{i j k l m n o}=$ probability of cows being alive at a certain lactation stage $(1=$ alive, $0=$ culled $)$. Other effects were the same as defined in Model [1].

Genetic Parameter Estimations. For LPL, a linear animal model was applied. In scalar notation, statistical Model [3] was as follows:

$$
\begin{aligned}
& y_{i j k l m n o p}=\mu+\Delta \mathrm{M}_{i}+D I M_{j}+H_{k}+J_{l}+S_{m}+F C A_{n} \\
& +A G_{o}+e_{i j k l m n o p}
\end{aligned}
$$

where $A G_{o}=$ random additive genetic effect. Other effects were the same as specified for Model [1].

For binary health traits and binary STAY, the following logistic animal model (Model [4]) was applied:

$$
\begin{aligned}
& \operatorname{logit}\left(\pi_{i j k l m n o}\right)=\log \left(\frac{\pi_{i j k l m n o}}{1-\pi_{i j k l m n o}}\right)=\mu+\Delta \mathrm{M}_{i}+D I M_{j} \\
& +H_{k}+J_{l}+S_{m}+F C A_{n}+A G_{o},
\end{aligned}
$$

with $\pi_{i j k l m n}=$ probability for the occurrence of the health disorder $(0=$ healthy, $1=$ diseased $)$ or for being alive in the respective lactation stage $(1=$ alive, $0=$ culled). Other effects were the same as defined in Model [1].

Genetic variance or covariance components were estimated via single-trait or bivariate animal models for all trait combinations. Heritabilities for binary traits were calculated using the variance of the logit link function, which implies a correction of the residual variance by factor $\pi^{2} / 3$ (Southey et al., 2003). Genetic correlations between binary STAY and binary health disorders were estimated via bivariate threshold-threshold models. For the runs including 1 Gaussian trait (LPL) and 1 binary trait (STAY or health disorders), bivariate threshold-linear models were applied. For estimation of genetic correlations between health disorders and LPL, we considered the disease ( 1 or 0 ) from the respective lactation stage. For the estimation of genetic correlations between STAY and diseases, we focused on STAY and diseases from the same lactation stage. To estimate genetic correlations between STAY and LPL, we considered the 0 or 1 trait coding for STAY from the 9 lactation stages in different runs.

The genetic (co)variance structure for bivariate linear models was

$$
\operatorname{var}\left[\begin{array}{l}
a \\
e
\end{array}\right]=\left[\begin{array}{cc}
\mathbf{G} \otimes \mathbf{A} & 0 \\
0 & \mathbf{R} \otimes \mathbf{I}_{\mathbf{n}}
\end{array}\right],
$$

where $\mathbf{G}$ was a $2 \times 2$ (co)variance matrix for the additive genetic effects of the 2 traits; $\mathbf{A}$ was the additive genetic relationship matrix based on pedigree; $\mathbf{R}$ was a $2 \times 2$ (co)variance matrix for residual effects; $\mathbf{I}_{\mathbf{n}}$ was an identity matrix for $n$ observations, and $\otimes$ was the direct matrix product. For estimation of genetic parameters, we used the AI-REML algorithm as implemented in the DMU software package (Madsen and Jensen, 2013).

\section{RESULTS AND DISCUSSION}

\section{Disease Incidences}

For biological reasons and associated very low disease incidences, some diseases were excluded from some stage-specific analyses. For instance, metabolic disorders typically occur shortly before or directly after calving (Probo et al., 2018). Consequently, we did not study the influence of metabolic disorders on longevity traits in second and third stages. Due to the relevance of MFEV only in later lactations (Erb et al., 1985), we considered MFEV only from stages L2.1 and L3.1. Full recovery of the uterus after calving requires 3 to 4 weeks (Sheldon and Owens, 2017), implying an ENDO diagnosis within the first 46 DIM (Gernand et al., 2012). In our study, a large percentage of cows diagnosed for ENDO in second stages was recorded for the same disease during first stages. Accordingly, we considered ENDO from second stages as the same disease. We excluded OCD, CYST, and CLP from first and third stages because they are generally diagnosed in the middle of lactation (Fleischer et al., 2001; Gernand 
et al., 2012). Retained placenta is relevant only for the first stages, directly after calving (Gernand et al., 2012; Koeck et al., 2012).

Lactation disease incidences (Table 1) from the German Holstein co-operator herd cows reflect results from other German federal states (Gernand et al., 2012). Generally, and in agreement with Heringstad et al. (2005), incidences of MAST, KET, MFEV, and RP increased with increasing lactation number. Hinrichs et al. (2011) reported highest mastitis rates during the early lactation period and a substantial decline afterward. In our study, MAST incidences in L1.1 and L1.2 were very similar. For later lactations, MAST incidences from the second stages were even larger than for the first stages. However, for the definition of the second stage, we considered a longer period than did most of the previous studies. The incidences for SU and DD in the early-lactation stage and on a lactation level were very similar to disease incidences from the same region 15 years ago (König et al., 2005). However, in the meantime, the health status for WLD and HYP appeared improved, possibly due to breeding and selection efforts. We found that DD incidences decreased with increasing lactation number from $15.03 \%$ in first to $12.82 \%$ in third lactation. Similarly, König et al. (2005) and Gernand et al. (2012) reported a decrease of infectious lesions with parity, explaining the decrease as being due to acquired resistance against specific bacteria. In agreement with Fleischer et al. (2001), the highest incidences for all claw diseases were identified in our study in the second stages. Collard et al. (2000) argued that periods of negative energy balance in the early lactation stage contribute to locomotive problems in the ongoing lactation. We observed quite high disease incidences for female fertility disorders. Lactation disease incidences for ENDO and OCD were higher than $20 \%$, indicating the health status decline for ovarian disorders in the past 25 years (Beaudeau et al., 1995; Gernand et al., 2012; Koeck et al., 2012). As expected, RP had relevance only in the early lactation stages, but CYST occurred in the middle of lactation. Lactation incidences for CYST in the range of 8 to $9.6 \%$ (Zwald et al., 2004a; Koeck et al., 2010) reflect the disease incidences from our study.

\section{Health-Related Culling Reasons}

Farmers' most frequent answers for cow culling reasons were udder diseases (24.21\%) and infertility $(21.72 \%)$, followed by claw disorders (16.97\%) and metabolic diseases $(12.84 \%)$. Thus, culling reasons for co-operator herd cows correspond with reports from the broader German Holstein population (Wangler et al., 2009) and with results from international studies (Egger-Danner et al., 2015). Figure 1 illustrates the frequencies of culling reasons for the different lactation stages. Culling frequencies due to udder diseases and claw disorders showed obvious peaks in the second stages for all lactations. The percentage of cows culled due to infertility increased from $0.31 \%$ in L1.1 to $21.52 \%$ in L1.3. The same pattern of culling reasons due to infertility was identified in later lactations. A small percentage of culled cows had the culling reason "metabolic disorders" in L1, but the frequency increased over ongoing lactations. Interestingly, the highest culling frequencies due to metabolic disorders were identified in the second stages of all 3 lactations, although the disease mostly occurred in the early lactation period (Table 1 ). Nevertheless, the distributions for culling reasons across stages and lactations are in agreement with reports by Pinedo et al. (2010) and Heise et al. (2016).

Table 2 depicts the associations between culling reasons as defined by farmers and diagnoses from the health trait data set. The culling reason database includes entries for all culled cows, in most cases disease specifications, but also culling due to low milk yield or "other problems." The health trait data set considers the diagnoses for specific diseases as defined by veterinarians. In the co-operator herd systems, veterinarians collaborate closely with breeding organizations, implying high health trait data quality. Cows with no disease entry in the health trait database are considered to be healthy for the respective lactation stage. We identified high agreements between the culling reasons "udder" (84.09\%) and "infertility" (76.03\%) with the corresponding recorded diseases. Nelson et al. (2010) reported that $13.8 \%$ of Norwegian Red cattle slaughtered due to reproductive problems (farmer information) were never diagnosed for any ovarian disorder. Nevertheless, apart from ovarian disorders, some other factors might cause infertility, such as poor cow nutrition or even the paternal components (semen quality of bulls). Our study detected some disagreements between culling reasons and diagnosed cow diseases for claw and metabolic disorders. For instance, only $45 \%$ of cows with the culling reason "claw disorders" had a corresponding claw disease diagnosis. Regarding the cows with metabolic diseases, the agreement with the culling reason "metabolism" was only $18.71 \%$. Heise et al. (2018) discussed the opportunities when including farmer information for cow culling reasons in official genetic evaluations. Due to the partly poor agreements with the health diagnoses, we assume biased EBV for health traits when additionally considering cow disposal information. Nevertheless, we assume additional value when considering farmers' culling reasons in genetic evaluations, because some cullings might be due to subclinical diseases, which are not fully reflected in the 
Table 2. Agreement between culling reasons as defined by farmers and veterinary disease diagnoses from the first 3 lactations ${ }^{1}$

\begin{tabular}{lccc}
\hline Culling reason & No. of culled cows & No. of cows with respective diagnoses & Percentage of cows with respective diagnoses \\
\hline Udder diseases & 14,213 & 11,952 & 84.09 \\
Infertility & 15,218 & 11,570 & 76.03 \\
Claw disorders & 9,602 & 4,321 & 45.00 \\
Metabolic diseases & 6,573 & 1,230 & 18.71 \\
\hline
\end{tabular}

${ }^{1}$ All culled cows have an entry for the culling reason in the database. Cows without diagnoses are considered to be healthy.

official diagnosis key. Alternatively, a disorder might already be so severe that there is no diagnosis, implying that the cow may be culled without consulting a veterinarian. With regard to the cow culling reason database, farmers are able to enter only one answer. However, in most cases, diseases appear to occur in clusters (König et al., 2005). Thus, we assume better agreements between culling reasons and real diseases when considering several culling reasons per cow.

\section{Phenotypic Influence of Diseases on Longevity}

Differences in least squares means for LPL (results from Model [1]) and for STAY probabilities (results from Model [2]) addressing the comparison of diseased versus healthy cows are given in Table 3 and Table 4, respectively. For all lactation stages, cows with a MAST diagnosis had a significantly shorter LPL than did healthy animals. The increased culling risk for cows with MAST diagnoses is in agreement with several previous studies (Schneider et al., 2007; Hultgren and Svensson, 2009). A MAST diagnosis from the early or middle lactation stages contributed to shorter LPL, as described by Neerhof et al. (2000) and Pinedo et al. (2010). In agreement with Roxström and Strandberg (2002), the effect of MAST from the late lactation stage on LPL was of minor importance. A MAST diagnosis strongly influenced STAY in the respective lactation stage but also contributed to time-lagged cow disposals in later lactation stages.

Effects of claw disorders on LPL differed among diseases and lactation stages. Diagnoses for SU, WLD, and HYP in all stages of L1 and L2 were associated with decrease in LPL. Charfeddine and Pérez-Cabal (2017) reported that occurrence of severe SU or WLD lesions contributed to LPL decline of 59 and $71 \mathrm{~d}$, respectively. Heringstad et al. (2018) identified negative energy balances for cows with noninfectious hoof lesions, and negative energy balance also influenced LPL. However, for the claw disorder DD, we identified an opposite effect on LPL. The surprising positive effect of DD infection on longevity was also pointed out by Booth et al. (2004) for diagnoses from calving up to 240 DIM. One explanation might be the strong unfavorable

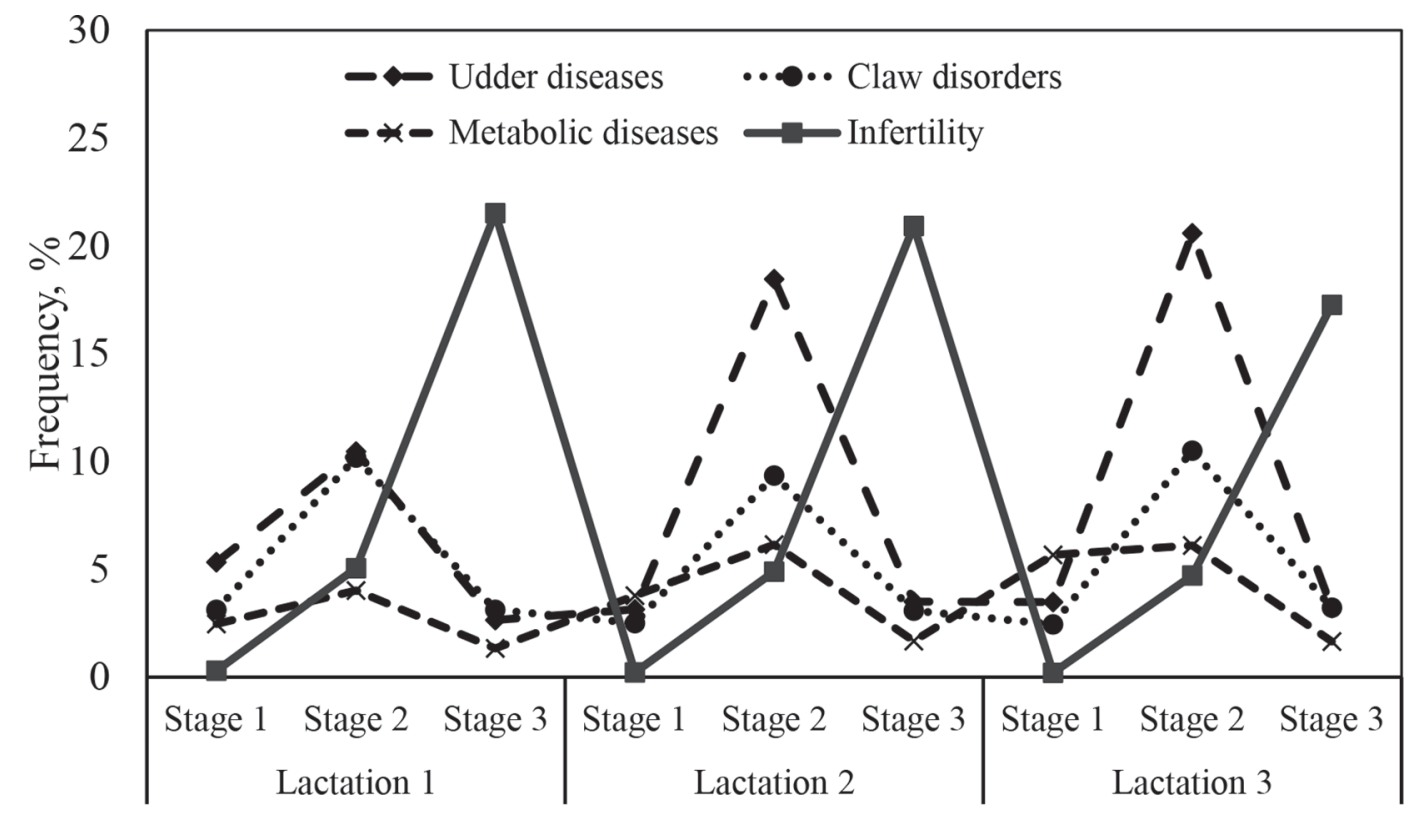

Figure 1. Distributions of culled cows (\%) for the culling reasons udder diseases, claw disorders, metabolic diseases, and infertility, as defined by farmers at different stages of the first 3 lactations. 
Table 3. Differences of LSM for the length of productive life (in days) for the comparison of diseased minus healthy cows by lactation stages ${ }^{1}$

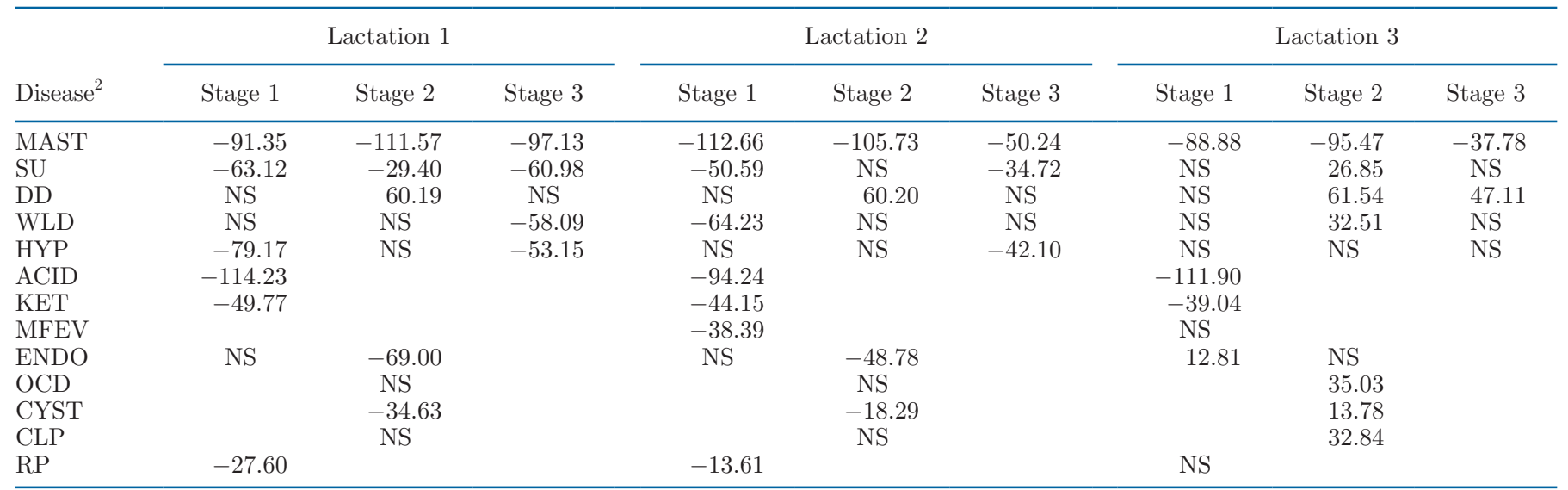

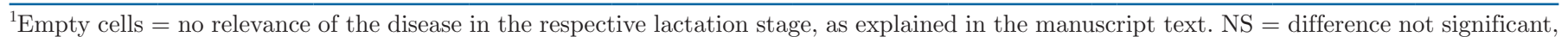
$P>0.05$.

${ }^{2} \mathrm{MAST}=$ clinical mastitis; $\mathrm{SU}=$ sole ulcer; $\mathrm{DD}=$ digital dermatitis; $\mathrm{WLD}=$ white line disease HYP = interdigital hyperplasia; $\mathrm{ACID}=$ ruminal acidosis; KET $=$ ketosis; $\mathrm{MFEV}=$ milk fever; ENDO $=$ endometritis; OCD $=$ ovarian cycle disorder; CYST $=$ ovarian cysts; CLP $=$ corpus luteum persistens; $\mathrm{RP}=$ retained placenta.

correlation between DD and protein yield (Gernand and König, 2014) and the strong selection intensity for production traits (König et al., 2007). Generally, DD seems to be a specific trait, differing in response from other claw disorders. In heat stress studies, Gernand et al. (2019) found a DD reduction with increasing temperature-humidity indices, the opposite of the remaining claw disorders. Among all claw disorders diagnosed early in lactation, only SU in L1.1 and L2.1was significantly associated with STAY. All claw disorders negatively influenced STAY in the late lactation stages. Hence, farmers treat and keep cows with claw problems throughout lactation, but these cows are not considered for later lactations (Booth et al., 2004).

Metabolic diseases from the early lactation period had strong detrimental effects on LPL. Accordingly, Probo et al. (2018) stated that all metabolic diseases, especially MFEV, are associated with increased culling risk in the first 120 DIM. Beaudeau et al. (1995) addressed the differences among longevity responses to fertility disorders, depending on the lactation stage. In their study, ENDO diagnosed between 22 and 49 DIM was not associated with longevity, but ENDO diagnosed afterward had significant detrimental effect. We

Table 4. Differences of LSM for stayability (in \%) for the comparison of diseased minus healthy cows by lactation stages ${ }^{1}$

\begin{tabular}{|c|c|c|c|c|c|c|c|c|c|}
\hline Disease $^{2}$ & \multicolumn{3}{|c|}{ Lactation 1} & \multicolumn{3}{|c|}{ Lactation 2} & \multicolumn{3}{|c|}{ Lactation 3} \\
\hline MAST & -1.66 & -5.44 & -6.88 & -1.01 & -7.59 & -5.88 & -0.88 & -8.33 & -6.16 \\
\hline DD & NS & 4.78 & -3.94 & NS & 5.72 & NS & NS & 7.34 & NS \\
\hline WLD & NS & NS & -8.56 & NS & 4.14 & -6.29 & NS & 4.04 & NS \\
\hline HYP & NS & 2.30 & -6.24 & NS & 3.33 & -4.57 & NS & 2.96 & NS \\
\hline ENDO & 0.88 & NS & & 0.75 & NS & & 1.35 & NS & \\
\hline OCD & & 1.42 & & & 1.31 & & & 3.43 & \\
\hline CYST & & 1.57 & & & 1.63 & & & 2.58 & \\
\hline CLP & & 1.65 & & & 1.97 & & & 3.65 & \\
\hline RP & NS & & & 0.27 & & & 0.55 & & \\
\hline
\end{tabular}

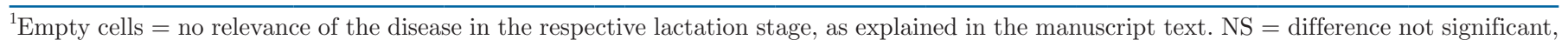
$P>0.05$

${ }^{2} \mathrm{MAST}=$ clinical mastitis; $\mathrm{SU}=$ sole ulcer; $\mathrm{DD}=$ digital dermatitis; $\mathrm{WLD}=$ white line disease; $\mathrm{HYP}=$ interdigital hyperplasia; $\mathrm{ACID}=$ ruminal acidosis; KET $=$ ketosis; $\mathrm{MFEV}=$ milk fever; $\mathrm{ENDO}=$ endometritis; OCD $=$ ovarian cycle disorder; CYST $=$ ovarian cysts; $\mathrm{CLP}=$ corpus luteum persistens; $\mathrm{RP}=$ retained placenta. 
found similar influences on LPL for ENDO diagnosed in L1 or L2 but not for ENDO in L3. As identified by Oltenacu et al. (1990), CYST and RP diagnosed in L1 and L2 negatively influenced LPL. However, a diagnosis of CYST or RP increased STAY probabilities for the same stages. Hence, there is a strong time-lagged effect of these female fertility disorders on longevity traitsthat is, no significant negative influence on STAY but detrimental effect on time-lagged LPL.

\section{Heritability Estimates}

Health Disorders. We found that heritability estimates for the 13 diseases across stages and lactations from single-trait generalized linear mixed models ranged from $<0.01$ to 0.24 (Table 5). Standard errors (SE) ranged from 0.007 to 0.017 for udder diseases, from 0.009 to 0.059 for claw disorders, from 0.023 to 0.105 for metabolic disorders, and from 0.006 to 0.025 for reproductive disorders. Heritabilities for MAST from different periods were in a stable range (0.05 to 0.08), confirming estimates from Neuenschwander et al. (2012), Pritchard et al. (2013b), and Parker Gaddis et al. (2014). Claw disorders showed stronger heritability alterations in different lactation stages. Heritabilities of SU varied between 0.06 and 0.12 , and from 0.09 to 0.13 for DD. In such context, König et al. (2005) discussed the possible effects of claw health pre-selection on disease incidences and genetic parameter alterations with increasing lactation number. In most lactation stages, heritabilities for WLD were low to moderate (0.11 to 0.19 ), and almost zero in L2.1. The largest claw disorder heritabilities were estimated for HYP (between 0.15 and 0.24 ). The potential for genetic HYP improvements, due to moderate heritabilties, was indicated in several previous studies (e.g., König et al., 2008b). For ACID, heritabilities were close to zero, in accord with the findings of Ederer et al. (2014), who reported low ACID heritabilities due to extremely low incidence and large environmental influence. Heritabilities for KET decreased from 0.13 in L1.1 to 0.08 in L3.1, similar to the KET heritability decrease with aging identified by Parker Gaddis et al. (2014). Also for KET, we assume strong selection against susceptible cows, explaining the decline of additive genetic variances and of heritabilities with increasing parity. By contrast, in agreement with Heringstad et al. (2005), heritabilities for MFEV increased from 0.08 in L2.1 to 0.13 in L3.1. Heritabilities for the liability of fertility diseases were quite small, in the range of 0.04 to 0.10 .

Longevity. The LPL heritability from the singletrait model was 0.05, with a small SE of 0.006 . Heritabilities from all bivariate runs, including LPL, ranged from 0.03 to 0.10 , also associated with small SE (0.003 to 0.008). Considering data from 19 countries, Forabosco et al. (2009) estimated heritabilities for direct longevity, via linear model applications, in the range from 0.02 to 0.11. In Czech Holstein cows, Zavadilová and Štípková (2012) and Zavadilová and Zink (2013) estimated heritabilities for LPL of 0.03 and

Table 5. Heritabilities for diseases by lactation stages ${ }^{1}$

\begin{tabular}{|c|c|c|c|c|c|c|c|c|c|}
\hline Disease $^{2}$ & \multicolumn{3}{|c|}{ Lactation 1} & \multicolumn{3}{|c|}{ Lactation 2} & \multicolumn{3}{|c|}{ Lactation 3} \\
\hline MAST & 0.08 & 0.05 & 0.07 & 0.06 & 0.07 & 0.05 & 0.05 & 0.06 & 0.06 \\
\hline DD & 0.09 & 0.10 & 0.09 & 0.10 & 0.10 & 0.12 & 0.10 & 0.09 & 0.13 \\
\hline WLD & 0.19 & $0.12^{3}$ & 0.18 & $0.15^{3}$ & $0.13^{3}$ & 0.11 & 0.11 & $0.09^{3}$ & 0.15 \\
\hline HYP & 0.18 & 0.22 & 0.23 & 0.17 & 0.20 & 0.24 & 0.21 & 0.19 & 0.15 \\
\hline ENDO & 0.06 & 0.07 & & 0.05 & 0.04 & & 0.04 & 0.06 & \\
\hline OCD & & 0.06 & & & 0.05 & & & 0.04 & \\
\hline CYST & & 0.06 & & & 0.05 & & & 0.05 & \\
\hline CLP & & 0.07 & & & $0.07^{3}$ & & & 0.05 & \\
\hline RP & 0.10 & & & 0.07 & & & 0.07 & & \\
\hline
\end{tabular}

${ }^{1}$ Empty cells $=$ no relevance of the disease in the respective lactation stage, as explained in the manuscript text. The SE ranged from 0.007 to 0.017 for udder diseases, from 0.009 to 0.059 for claw disorders, from 0.023 to 0.105 for metabolic disorders, from 0.006 to 0.025 for reproductive disorders.

${ }^{2} \mathrm{MAST}=$ clinical mastitis; $\mathrm{SU}=$ sole ulcer; $\mathrm{DD}=$ digital dermatitis; $\mathrm{WLD}=$ white line disease HYP = interdigital hyperplasia; $\mathrm{ACID}=$ ruminal acidosis; KET = ketosis; MFEV = milk fever; ENDO = endometritis; OCD = ovarian cycle disorder; CYST = ovarian cysts; CLP = corpus luteum persistens; $\mathrm{RP}=$ retained placenta.

${ }^{3}$ These runs did not fully converge with the default convergence criteria "norm of update vector room" $=1 \times 10^{-7}$ and "norm of gradient vector" $=1 \times 10^{-6}$. In consequence, we slightly lowered the criteria to $1 \times 10^{-6}$ and $1 \times 10^{-5}$, respectively. 
0.09, respectively. In Spanish Holsteins, LPL heritabilities ranged from 0.08 to 0.10 (Pérez-Cabal and Alenda, 2003; Pérez-Cabal et al., 2006). In UK Holsteins, based on linear mixed model applications, heritabilities for both longevity definitions LPL and days of life were 0.06 (Pritchard et al., 2013b). In the Swedish Holstein population, LPL heritabilities were in the range of 0.09 to 0.13 (Ahlman et al., 2011). According to the genetic parameter estimates from different countries, heritabilities in European Holstein populations are very similar for LPL, irrespective of the statistical modeling approach (linear or threshold model applications).

Nevertheless, alternative LPL definitions were also addressed from a quantitative genetic perspective in past studies. VanRaden et al. (2006) defined LPL as the period from calving up to a particular month of age, but heritabilities in the range from 0.02 to 0.07 were almost identical compared with the "conventional" LPL definition. Tsuruta et al. (2005) developed longevity models considering restrictions for lactation length. Again, heritabilities were in the narrow range from 0.08 to 0.10. Van Pelt et al. (2015) considered the last official test date when defining the period for LPL, but heritabilities increased only marginally. At present, routine genetic evaluations of longevity mostly use survival analysis. Similar to our LPL heritabilities based on uncensored data, LPL heritabilities from the Weibull proportional hazards models were also in the range from 0.05 and 0.09 (Chirinos et al., 2007; Strapáková et al., 2013; Morek-Kopeć and Zarnecki, 2017), for both important European dairy and dual-purpose breeds Holstein and Fleckvieh. Thus there is only a small to moderate genetic background influencing longevity. Via survival analyses, Buenger et al. (2001) identified some other important environmental factors with larger effects on LPL, such as housing or bedding systems.

As a further longevity trait definition and statistical modeling alternative, we evaluated binary STAY and applied single-trait generalized linear mixed models with a logit link function for heritability estimations. The STAY heritabilities were quite stable for the different lactation stages, in the range from 0.05 to 0.06 , with small SE between 0.008 and 0.033 . In agreement with our results, heritability estimates for binary STAY via bivariate or multivariate threshold models ranged from 0.04 to 0.11 (González-Recio and Alenda, 2007; Holtsmark et al., 2008; Tsuruta et al., 2015). Studies addressing both linear and threshold modeling found high correlations with sire EBV (Boettcher et al., 1999; van Pelt et al., 2015). Against this background of nearly identical EBV and heritabilities from both approaches, linear models were suggested because of the computation time requirements (e.g., van Pelt et al., 2015).
We observed a slight increase of STAY heritabilities in later lactations and in later lactation stages. Ahlman et al. (2011) estimated STAY heritabilities, via bivariate linear-linear models, of $0.05,0.08$ and 0.20 for the first, second, and third lactations, respectively. Among Canadian Holsteins, Sewalem et al. (2007) also found larger STAY heritabilities in later parities. Wiebelitz et al. (2014) created 2 stages within lactations. Comparable to our results, STAY heritabilities were slightly larger in the late lactation stages. The definition of smaller time windows (up to 6 periods) contributed to stronger heritability alterations, ranging from 0.04 to 0.11 (Heise et al., 2016). Heritabilities for categorical traits depend on the frequencies of cows in different classes - that is, the percentage of diseased cows (Heringstad et al., 2000). Hence, the larger proportion of culled cows in later stages or lactations might be an explanation for the slight heritability increase.

\section{Genetic Correlations Between Longevity Traits and Diseases}

Genetic correlations between LPL and STAY with the studied diseases are listed in Table 6 and Table 7 , respectively. Favorable genetic correlations between LPL and MAST from different stages $(-0.28$ to -0.69$)$, and between STAY and MAST ( -0.26 to -0.77$)$, suggest reason to perform selection on udder health at early stages of life, to improve longevity genetically. The negative correlations between MAST and LPL and between MAST and STAY reflect estimates from the United Kingdom (Pritchard et al., 2013a) and in Danish Holstein cows (Sander Nielsen et al., 1999). Different modeling approaches have been applied in the different studies. Nevertheless, with regard to bivariate modeling strategies, results are comparable, because Vinson and Kluwer (1976) showed that genetic correlations from linear-linear and from linear-threshold models can be expected to be the same. Especially for the 3 stages of first lactation, MAST and STAY showed quite strong genetic relationships. The most obvious change in genetic correlations between diseases and STAY was observed for the transition from the second to the third lactation stage. Differences in genetic (co) variance components when comparing early and middle with late lactation stages have been identified for diseases (Zwald et al., 2006) and for STAY (Wiebelitz et al., 2014).

Genetic correlations between claw disorders with LPL and with STAY were also mostly negative, indicating that selection for improved claw health is associated with indirect favorable selection response in longevity traits. Favorable (i.e., negative) genetic correlations 
between claw disorders and longevity were reported by Sander Nielsen et al. (1999), considering survival from second lactations and the feet and leg diseases HYP and SU in Danish Holsteins, and by Pritchard et al. (2013a), who focused on a lifespan score and lameness for Holsteins in the United Kingdom. Again, as identified phenotypically, a DD diagnosis from some lactation stages was genetically unfavorably associated with LPL and with STAY. The different phenotypic and genetic mechanisms of DD, compared with the remaining claw disorders, suggest a need for ongoing studies in this regard. In Dutch Holstein cows, genetic correlations between DD and lifespan were close to zero but slightly negative (Onyiro et al., 2008). Dhakal et al. (2015) estimated a genetic correlation of -0.03 between DD and LPL for the US Holstein population. Genetic correlations between SU with STAY and with LPL decreased with increasing lactation number, suggesting reason to focus on indirect selection strategies on $\mathrm{SU}$ especially in parities 2 and 3 when aiming for longevity improvements. For WL and HYP, we observed different genetic correlation trends when comparing associations with either LPL or STAY. However, the quite large SE for genetic correlation estimates should be taken into consideration. The comparatively large SE could be due to the low disease incidences for WL and HYP in some lactation stages (van der Waaij et al., 2005).

Metabolic diseases, especially ACID and KET, had strong genetic effects on longevity, with genetic correlations up to -0.98 . However, as for the metabolic disease with low incidences, these genetic correlations had quite large SE. Genetic correlations from -0.10 to -0.17 among metabolic diseases and longevity were estimated by Sander Nielsen et al. (1999) and Zwald et al. (2004b) for Danish and US Holstein populations, respectively. Diagnoses for ACID and KET in L1, as well as for MFEV in L2, had most obvious detrimental genetic effects on LPL. However, incidences for these diseases were higher in later lactations. Both longevity traits LPL and STAY were negatively correlated with female fertility disorders, implying that selection on lower disease incidences will contribute to genetic longevity improvements. In this regard, the genetic correlations between ENDO, OCD, and RP with longevity

Table 6. Genetic correlations between length of productive life and diseases recorded in different lactation stages; SE are presented below estimates $^{1}$

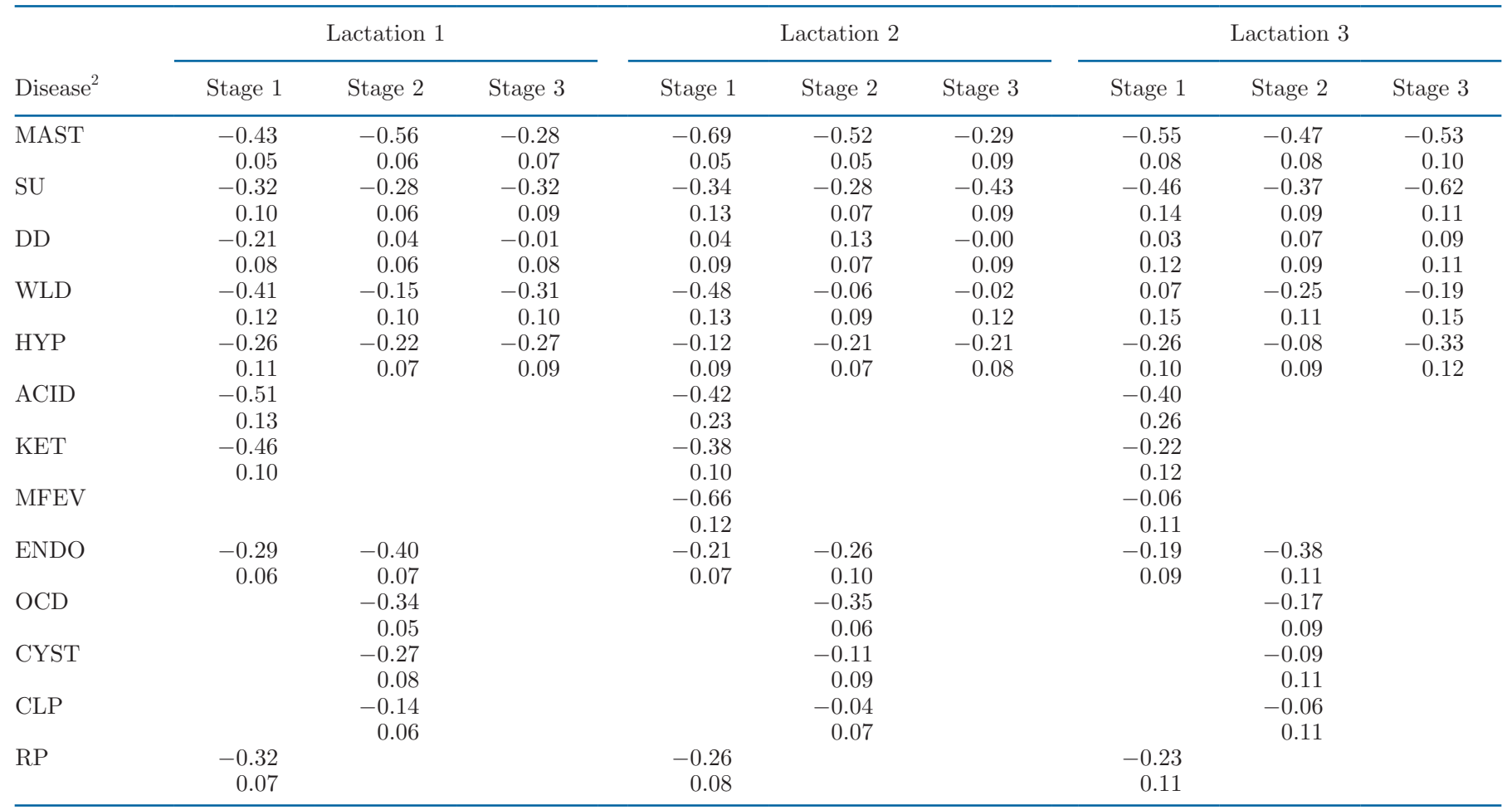

${ }^{1}$ Empty cells $=$ no relevance of the disease in the respective lactation stage, as explained in the manuscript text.

${ }^{2} \mathrm{MAST}=$ clinical mastitis; $\mathrm{SU}=$ sole ulcer; $\mathrm{DD}=$ digital dermatitis; WLD = white line disease; HYP = interdigital hyperplasia; $\mathrm{ACID}=$ ruminal acidosis; KET $=$ ketosis; $\mathrm{MFEV}=$ milk fever; $\mathrm{ENDO}=$ endometritis; $\mathrm{OCD}=$ ovarian cycle disorder; $\mathrm{CYST}=$ ovarian cysts; $\mathrm{CLP}=$ corpus luteum persistens; $\mathrm{RP}=$ retained placenta. 
Table 7. Genetic correlations between stayability and diseases from the same lactation stages; SE are presented below estimates ${ }^{1}$

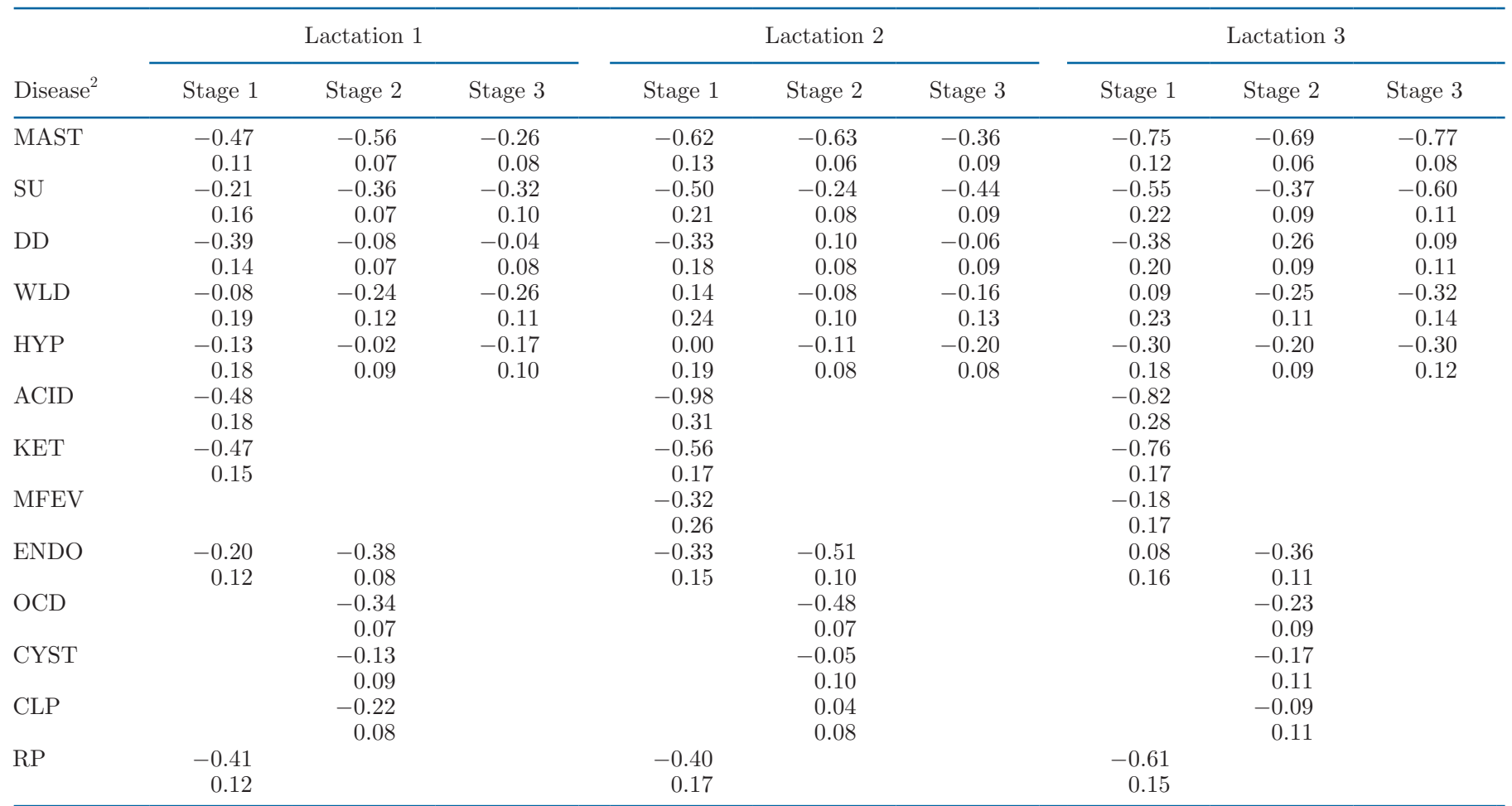

${ }^{1}$ Empty cells $=$ no relevance of the disease in the respective lactation stage, as explained in the manuscript text.

${ }^{2}$ MAST $=$ clinical mastitis; $\mathrm{SU}=$ sole ulcer DD = digital dermatitis; $\mathrm{WLD}=$ white line disease HYP = interdigital hyperplasia; $\mathrm{ACID}=$ ruminal acidosis; KET $=$ ketosis; MFEV $=$ milk fever; $\mathrm{ENDO}=$ endometritis; $\mathrm{OCD}=$ ovarian cycle disorder; $\mathrm{CYST}=$ ovarian cysts; $\mathrm{CLP}=$ corpus luteum persistens; $\mathrm{RP}=$ retained placenta.

traits were stronger than for CYST and CLP. Genetic associations between female fertility disorders and longevity in other Holstein populations followed the same pattern as that identified in our study - for instance, in Danish Holsteins with regard to RP, CYST, and ENDO (Sander Nielsen et al., 1999), and in US Holsteins for CYST and ENDO (Zwald et al., 2004b).

Genetic correlations between LPL and STAY across stages and lactations were quite large, in the range from 0.77 to 0.94 (Table 8). Hence, both longevity definitions LPL and STAY are genetically the same trait, as previously indicated (Short and Lawlor, 1992; Jairath et al., 1998; van Pelt et al., 2015). In this regard, we suggest selection on STAY in early lactations, to select young animals with high accuracy and simultaneously reduce generation intervals.

\section{CONCLUSIONS}

We observed some disagreements between culling reasons, as subjectively defined by farmers, and veterinary diagnoses for cow diseases. Thus, despite the availability of large population-wide data sets for culling reasons, we suggest focusing on veterinarian diagnoses from cows in co-operator herds for genetic evaluations of health traits and when defining appropriate longevity indicators in survival analyses. Nevertheless, some cullings might be due to subclinical diseases, which are

Table 8. Genetic correlations between the length of productive life and stayability from different lactation stages

\begin{tabular}{|c|c|c|c|c|c|c|c|c|c|}
\hline \multirow[b]{2}{*}{ Item } & \multicolumn{3}{|c|}{ Lactation 1} & \multicolumn{3}{|c|}{ Lactation 2} & \multicolumn{3}{|c|}{ Lactation 3} \\
\hline & Stage 1 & Stage 2 & Stage 3 & Stage 1 & Stage 2 & Stage 3 & Stage 1 & Stage 2 & Stage 3 \\
\hline $\mathrm{SE}$ & 0.07 & 0.03 & 0.02 & 0.10 & 0.02 & 0.02 & 0.11 & 0.04 & 0.04 \\
\hline
\end{tabular}


not fully reflected in the veterinarian diagnosis key, indicating additional information from the farmer culling answers in genetic evaluations. With regard to the monitored diseases, diagnoses for MAST and metabolic diseases had strong detrimental phenotypic effects on LPL and on STAY. Most of the disease traits had only small to moderate heritabilities, but MAST, SU, and metabolic disorders were strongly genetically correlated with LPL and STAY. Heritabilities for the different longevity definitions LPL and STAY across stages and lactations were quite stable in the range from 0.05 to 0.06. Genetic correlations between LPL and STAY from different periods were quite large (0.77 to 0.94), indicating similarities between the 2 trait definitions and suggesting the utility of early selection strategies based on STAY information.

\section{ACKNOWLEDGMENTS}

The project was supported by funds from the Federal Ministry of Food and Agriculture (BMEL, Bonn, Germany), based on a decision of the parliament of the Federal Republic of Germany via the Federal Office for Agriculture and Food (BLE), under the Federal Programme for Ecological Farming and Other Forms of Sustainable Agriculture.

\section{REFERENCES}

ADR (Arbeitsgemeinschaft Deutscher Rinderzüchter e.V.). 2017. ADR-Empfehlung 3.1: Leistungsprüfung für funktionale Merkmale bei Bullen und Kühen (Gesundheit, Reproduktion, Nutzungsdauer, Exterieur, Melkbarkeit). Accessed Apr. 18, 2018. https:// www.rind-schwein.de/services/files/adr/richtlinien-empfehlungen/ 20170516\%20ADR-Empfehlung\%203.1.pdf.

Ahlman, T., B. Berglund, L. Rydhmer, and E. Strandberg. 2011. Culling reasons in organic and conventional dairy herds and genotype by environment interaction for longevity. J. Dairy Sci. 94:1568 1575. https://doi.org/10.3168/jds.2010-3483.

Beaudeau, F., V. Ducrocq, C. Fourichon, and H. Seegers. 1995. Effect of disease on length of productive life of French Holstein dairy cows assessed by survival analysis. J. Dairy Sci. 78:103-117. https: //doi.org/10.3168/jds.S0022-0302(95)76621-8.

Boettcher, P., L. Jairath, and J. Dekkers. 1999. Genetic evaluation of herd life in Canada: Current status and future outlook. In Proc. Workshop on Genetic Improvement of Functional Traits in Cattle (GIFT), Jouy-en-Josas, France. Interbull Bull. 21:23-30.

Booth, C. J., L. D. Warnick, Y. T. Gröhn, D. O. Maizon, C. L. Guard, and D. Janssen. 2004. Effect of lameness on culling in dairy cows. J. Dairy Sci. 87:4115-4122. https://doi.org/10.3168/jds.S0022 -0302(04)73554-7.

Buenger, A., V. Ducrocq, and H. H. Swalve. 2001. Analysis of survival in dairy cows with supplementary data on type scores and housing systems from a region of northwest Germany. J. Dairy Sci. $84: 1531-1541$

Charfeddine, N., and M. A. Pérez-Cabal. 2017. Effect of claw disorders on milk production, fertility, and longevity, and their economic impact in Spanish Holstein cows. J. Dairy Sci. 100:653-665. https: //doi.org/10.3168/jds.2016-11434.

Chirinos, Z., M. J. Carabaño, and D. Hernández. 2007. Genetic evaluation of length of productive life in the Spanish Holstein-Friesian population. Model validation and genetic parameters estimation.
Livest. Sci. 106:120-131. https://doi.org/10.1016/j.livsci.2006.07 .006 .

Collard, B. L., P. J. Boettcher, J. C. Dekkers, D. Petitclerc, and L. R. Schaeffer. 2000. Relationships between energy balance and health traits of dairy cattle in early lactation. J. Dairy Sci. 83:2683-2690. https://doi.org/10.3168/jds.S0022-0302(00)75162-9.

Dhakal, K., F. Tiezzi, J. S. Clay, and C. Maltecca. 2015. Short communication: Genomic selection for hoof lesions in first-parity US Holsteins. J. Dairy Sci. 98:3502-3507. https://doi.org/10.3168/jds .2014-8830.

Ederer, S., C. Egger-Danner, W. Zollitsch, and B. Fuerts-Walt. 2014. Metabolic disorders and their relationships to milk production traits in Austrian Fleckvieh. In Proc. 39th International Committee for Animal Recording (ICAR) meeting, Berlin, Germany. Accessed Jul. 10, 2018. https://www.icar.org/wp-content/uploads/ 2015/09/Fuerst_Waltl.pdf.

Egger-Danner, C., J. B. Cole, J. E. Pryce, N. Gengler, B. Heringstad, A. Bradley, and K. F. Stock. 2015. Invited review: Overview of new traits and phenotyping strategies in dairy cattle with a focus on functional traits. Animal 9:191-207. https://doi.org/10.1017/ S1751731114002614.

Erb, H. N., R. D. Smith, P. A. Oltenacu, C. L. Guard, R. B. Hillman, P. A. Powers, M. C. Smith, and M. E. White. 1985. Path model of reproductive disorders and performance, milk fever, mastitis, milk yield, and culling in Holstein cows. J. Dairy Sci. 68:3337-3349. https://doi.org/10.3168/jds.S0022-0302(85)81244-3.

Feucker, W., and R. Staufenbiel. 2003. Zentraler Diagnoseschlüssel Rind. Accessed Jul. 3, 2017. www.portal-rind.de/index.php ? module $=$ Downloads\&func $=$ prep_hand_out\&lid $=17$.

Fleischer, P., M. Metzner, M. Beyerbach, M. Hoedemaker, and W. Klee. 2001. The relationship between milk yield and the incidence of some diseases in dairy cows. J. Dairy Sci. 84:2025-2035. https:/ /doi.org/10.3168/jds.S0022-0302(01)74646-2.

Forabosco, F., J. H. Jakobsen, and W. F. Fikse. 2009. International genetic evaluation for direct longevity in dairy bulls. J. Dairy Sci. 92:2338-2347. https://doi.org/10.3168/jds.2008-1214.

Gernand, E., and S. König. 2014. Short communication: Genetic relationships between claw disorders, protein yield, and somatic cell score by days in milk. J. Dairy Sci. 97:5872-5879. https://doi.org/ 10.3168/jds.2013-7612.

Gernand, E., S. König, and C. Kipp. 2019. Influence of on-farm measurements for heat stress indicators on dairy cow productivity female fertility, and health. J. Dairy Sci. https://doi.org/10.3168/ jds.2018-16011.

Gernand, E., P. Rehbein, U. U. von Borstel, and S. König. 2012. Incidences of and genetic parameters for mastitis, claw disorders, and common health traits recorded in dairy cattle contract herds. J. Dairy Sci. 95:2144-2156. https://doi.org/10.3168/jds.2011-4812.

González-Recio, O., and R. Alenda. 2007. Genetic relationship of discrete-time survival with fertility and production in dairy cattle using bivariate models. Genet. Sel. Evol. 39:391-404. https://doi .org/10.1051/gse:2007010.

Heise, J., Z. Liu, K. F. Stock, S. Rensing, F. Reinhardt, and H. Simianer. 2016. The genetic structure of longevity in dairy cows. J. Dairy Sci. 99:1253-1265. https://doi.org/10.3168/jds.2015-10163.

Heise, J., K. F. Stock, S. Rensing, and H. Simianer. 2018. Potential use of routinely reported disposal reasons in dairy cattle breeding. Zuchtungskunde 1:13-26.

Heringstad, B., Y. M. Chang, D. Gianola, and G. Klemetsdal. 2005. Genetic analysis of clinical mastitis, milk fever, ketosis, and retained placenta in three lactations of Norwegian Red cows. J. Dairy Sci. 88:3273-3281. https://doi.org/10.3168/jds.S0022 -0302(05)73010-1.

Heringstad, B., C. Egger-Danner, N. Charfeddine, J. E. Pryce, K. F. Stock, J. Kofler, A. M. Sogstad, M. Holzhauer, A. Fiedler, K. Müller, P. Nielsen, G. Thomas, N. Gengler, G. de Jong, C. Ødegård, F. Malchiodi, F. Miglior, M. Alsaaod, and J. B. Cole. 2018. Invited review: Genetics and claw health: Opportunities to enhance claw health by genetic selection. J. Dairy Sci. 101:4801-4821. https:// doi.org/10.3168/jds.2017-13531. 
Heringstad, B., G. Klemetsdal, and J. Ruane. 2000. Selection for mastitis resistance in dairy cattle: A review with focus on the situation in the Nordic countries. Livest. Prod. Sci. 64:95-106. https://doi .org/10.1016/S0301-6226(99)00128-1.

Hinrichs, D., J. Bennewitz, E. Stamer, W. Junge, E. Kalm, and G. Thaller. 2011. Genetic analysis of mastitis data with different models. J. Dairy Sci. 94:471-478. https://doi.org/10.3168/jds.2010 -3374 .

Holtsmark, M., B. Heringstad, P. Madsen, and J. Ødegård. 2008. Genetic relationship between culling, milk production, fertility, and health traits in Norwegian red cows. J. Dairy Sci. 91:4006-4012. https://doi.org/10.3168/jds.2007-0816.

Hultgren, J., and C. Svensson. 2009. Heifer rearing conditions affect length of productive life in Swedish dairy cows. Prev. Vet. Med. 89:255-264. https://doi.org/10.1016/j.prevetmed.2009.02.012.

Interbull. 2016. Code of Practice. Accessed Aug. 9, 2018. http://www .interbull.org/ib/codeofpractice.

Jairath, L., J. Dekkers, L. R. Schaeffer, Z. Liu, E. B. Burnside, and B. Kolstad. 1998. Genetic evaluation for herd life in Canada. J. Dairy Sci. 81:550-562. https://doi.org/10.3168/jds.S0022-0302(98)75607 -3 .

Klein, S. L., C. Scheper, K. Brügemann, H. H. Swalve, and S. König. 2019. Phenotypic relationships, genetic parameters, genome-wide associations and identification of potential candidate genes for ketosis and fat-to-protein ratio in German Holstein cows. J. Dairy Sci. https://doi.org/10.3168/jds.2019-16237.

Koeck, A., C. Egger-Danner, C. Fuerst, W. Obritzhauser, and B. Fuerst-Waltl. 2010. Genetic analysis of reproductive disorders and their relationship to fertility and milk yield in Austrian Fleckvieh dual-purpose cows. J. Dairy Sci. 93:2185-2194. https://doi.org/10 $.3168 /$ jds.2009-2570.

Koeck, A., F. Miglior, D. F. Kelton, and F. S. Schenkel. 2012. Health recording in Canadian Holsteins: Data and genetic parameters. J. Dairy Sci. 95:4099-4108. https://doi.org/10.3168/jds.2011-5127.

König, S., K. Brügemann, H. Simianer, and H. H. Swalve. 2008a. Test herds in dairy cattle breeding programmes. 2nd communication: Strategies for finding test herds. Zuchtungskunde 80:114-126.

König, S., S. Lessner, and H. Simianer. 2007. Application of controlling instruments for improvements in cow sire selection. J. Dairy Sci. 90:1967-1980. https://doi.org/10.3168/jds.2006-473.

König, S., A. R. Sharifi, H. Wentrot, D. Landmann, M. Else, and H. Simianer. 2005. Genetic parameters of claw and foot disorders estimated with logistic models. J. Dairy Sci. 88:3316-3325.

König, S., X. L. Wu, D. Gianola, B. Heringstad, and H. Simianer. 2008b. Exploration of relationships between claw disorders and milk yield in Holstein cows via recursive linear and threshold models. J. Dairy Sci. 91:395-406. https://doi.org/10.3168/jds.2007 -0170 .

Madsen, P., and J. Jensen. 2013. A User's Guide to DMU—A package for analysing multivariate mixed models. Version 6, release 5.2. University of Aarhus, Research Centre Foulum, Denmark.

Morek-Kopeć, M., and A. Zarnecki. 2017. Genetic evaluation for functional longevity in Polish Simmental cattle. Czech J. Anim. Sci. 62:276-286. https://doi.org/10.17221/87/2016-CJAS.

Neerhof, H. J., P. Madsen, V. P. Ducrocq, A. R. Vollema, J. Jensen, and I. R. Korsgaard. 2000. Relationships between mastitis and functional longevity in Danish Black and White dairy cattle estimated using survival analysis. J. Dairy Sci. 83:1064-1071. https:/ /doi.org/10.3168/jds.S0022-0302(00)74970-8.

Nelson, S. T., A. D. Martin, and O. Østerås. 2010. Risk factors associated with cystic ovarian disease in Norwegian dairy cattle. Acta Vet. Scand. 52:60. https://doi.org/10.1186/1751-0147-52-60.

Neuenschwander, T. F.-O., F. Miglior, J. Jamrozik, O. Berke, D. F. Kelton, and L. R. Schaeffer. 2012. Genetic parameters for producer-recorded health data in Canadian Holstein cattle. Animal 6:571-578. https://doi.org/10.1017/S1751731111002059.

Oltenacu, P. A., A. Frick, and B. Lindhé. 1990. Epidemiological study of several clinical diseases, reproductive performance and culling in primiparous Swedish cattle. Prev. Vet. Med. 9:59-74. https://doi .org/10.1016/0167-5877(90)90042-G.
Onyiro, O. M., L. J. Andrews, and S. Brotherstone. 2008. Genetic parameters for digital dermatitis and correlations with locomotion, production, fertility traits, and longevity in Holstein-Friesian dairy cows. J. Dairy Sci. 91:4037-4046.

Parker Gaddis, K. L., J. B. Cole, J. S. Clay, and C. Maltecca. 2014. Genomic selection for producer-recorded health event data in US dairy cattle. J. Dairy Sci. 97:3190-3199. https://doi.org/10.3168/ jds.2013-7543.

Pérez-Cabal, M. A., and R. Alenda. 2003. Lifetime profit as an individual trait and prediction of its breeding values in Spanish Holstein cows. J. Dairy Sci. 86:4115-4122. https://doi.org/10.3168/ jds.S0022-0302(03)74025-9.

Pérez-Cabal, M. A., C. García, O. González-Recio, and R. Alenda. 2006. Genetic and phenotypic relationships among locomotion type traits, profit, production, longevity, and fertility in Spanish dairy cows. J. Dairy Sci. 89:1776-1783. https://doi.org/10.3168/ jds.S0022-0302(06)72246-9.

Philipsson, J., and B. Lindhé. 2003. Experiences of including reproduction and health traits in Scandinavian dairy cattle breeding programmes. Livest. Prod. Sci. 83:99-112. https://doi.org/10.1016/ S0301-6226(03)00047-2.

Pinedo, P. J., A. De Vries, and D. W. Webb. 2010. Dynamics of culling risk with disposal codes reported by Dairy Herd Improvement dairy herds. J. Dairy Sci. 93:2250-2261. https://doi.org/10.3168/ jds.2009-2572.

Pritchard, T., M. Coffey, R. Mrode, and E. Wall. 2013a. Genetic parameters for production, health, fertility and longevity traits in dairy cows. Animal 7:34-46. https://doi.org/10.1017/ S1751731112001401.

Pritchard, T., M. Coffey, R. Mrode, and E. Wall. 2013b. Understanding the genetics of survival in dairy cows. J. Dairy Sci. 96:32963309. https://doi.org/10.3168/jds.2012-6219.

Probo, M., O. B. Pascottini, S. LeBlanc, G. Opsomer, and M. Hostens. 2018. Association between metabolic diseases and the culling risk of high-yielding dairy cows in a transition management facility using survival and decision tree analysis. J. Dairy Sci. 101:94199429. https://doi.org/10.3168/jds.2018-14422.

R Development Core Team. 2017. R: A language and environment for statistical computing. R Core Team, Vienna, Austria.

Roxström, A., and E. Strandberg. 2002. Genetic analysis of functional, fertility-, mastitis-, and production-determined length of productive life in Swedish dairy cattle. Livest. Prod. Sci. 74:125-135. https://doi.org/10.1016/S0301-6226(01)00300-1.

Sander Nielsen, U., A. G. Pedersen, J. Pedersen, and J. Jensen. 1999. Genetic variation in disease traits and their relationships with survival in Danish dairy cattle. Interbull Bull. 21:170-178.

Schneider, M. P., E. Strandberg, U. Emanuelson, K. Grandinson, and A. Roth. 2007. The effect of veterinary-treated clinical mastitis and pregnancy status on culling in Swedish dairy cows. Prev. Vet. Med. 80:179-192. https://doi.org/10.1016/j.prevetmed.2007.02 .006 .

Sewalem, A., F. Miglior, G. J. Kistemaker, P. Sullivan, G. Huapaya, and B. J. van Doormaal. 2007. Short communication: Modification of genetic evaluation of herd life from a three-trait to a five-trait model in Canadian dairy cattle. J. Dairy Sci. 90:2025-2028. https: //doi.org/10.3168/jds.2006-719.

Sheldon, I. M., and S. E. Owens. 2017. Postpartum uterine infection and endometritis in dairy cattle. Anim. Reprod. 14:622-629. https: //doi.org/10.21451/1984-3143-AR1006.

Short, T. H., and T. J. Lawlor. 1992. Genetic parameters of conformation traits, milk yield, and herd life in Holsteins. J. Dairy Sci. 75:1987-1998. https://doi.org/10.3168/jds.S0022-0302(92)77958 -2 .

Southey, B. R., S. L. Rodriguez-Zas, and K. A. Leymaster. 2003. Discrete time survival analysis of lamb mortality in a terminal sire composite population. J. Anim. Sci. 81:1399-1405. https://doi $. \operatorname{org} / 10.2527 / 2003.8161399 x$.

Stock, K. F., J. Cole, J. Pryce, N. Gengler, A. Bradley, L. Andrews, B. Heringstad, and C. Egger-Danner. 2013. Standardization of health data-ICAR guidelines including health key. ICAR Tech. Ser. 17:75-81. 
Strapáková, E., J. Candrák, P. Strapák, and A. Trakovická. 2013. Genetic evaluation of the functional productive life in Slovak Simmental cattle. Arch. Tierzucht 59:797-807.

Tsuruta, S., D. A. L. Lourenco, I. Misztal, and T. J. Lawlor. 2015. Genotype by environment interactions on culling rates and 305d milk yield of Holstein cows in three US regions. J. Dairy Sci. 98:5796-5805. https://doi.org/10.3168/jds.2014-9242.

Tsuruta, S., I. Misztal, and T. J. Lawlor. 2005. Changing definition of productive life in US Holsteins: Effect on genetic correlations. J. Dairy Sci. 88:1156-1165. https://doi.org/10.3168/jds.S0022 -0302(05)72782-X.

van der Waaij, E. H., M. Holzhauer, E. Ellen, C. Kamphuis, and G. de Jong. 2005. Genetic parameters for claw disorders in Dutch dairy cattle and correlations with conformation traits. J. Dairy Sci. 88:3672-3678. https://doi.org/10.3168/jds.S0022-0302(05)73053 $-8$.

van Pelt, M. L., T. H. E. Meuwissen, G. de Jong, and R. F. Veerkamp. 2015. Genetic analysis of longevity in Dutch dairy cattle using random regression. J. Dairy Sci. 98:4117-4130. https://doi.org/10 $.3168 /$ jds.2014-9090.

VanRaden, P. M., C. M. B. Dematawewa, R. E. Pearson, and M. E. Tooker. 2006. Productive life including all lactations and longer lactations with diminishing credits. J. Dairy Sci. 89:3213-3220. https://doi.org/10.3168/jds.S0022-0302(06)72596-6.

Vinson, W. E., and R. W. Kluwer. 1976. Overall classification as a selection criterion for improving categorically scored components of type in Holstein. J. Dairy Sci. 59:2104-2114.

VIT. 2018. Beschreibung der Zuchtwertschätzung für Milchleistungsmerkmale, Zellzahl, Exterieurmerkmale, Nutzungs- dauer und Zuchtleistungsmerkmale. Accessed Aug. 9, 2018. https://www.vit .de/fileadmin/DE/Zuchtwertschaetzung/Zws_Bes_deu.pdf.

Wangler, A., E. Blum, I. Boettcher, and P. Sanftleben. 2009. Productive life and longevity of dairy cows on the basis of efficiency of milk production. Zuchtungskunde 81:341-360.
Wiebelitz, J., F. Reinhardt, Z. Liu, M. Erbe, and H. Simianer. 2014 Genetic evaluation of survival traits in German Holstein dairy cattle using a six-trait linear model. In Proc. 10th World Congr. Genet. Appl. Livest. Prod. Canada. Accessed Apr. 2, 2019. http: //wcgalp.org/system/files/proceedings/2014/genetic-evaluation -survival-traits-german-holstein-dairy-cattle-using-six-trait-linear -model.pdf.

Zavadilová, L., and M. Štípková. 2012. Genetic correlations between longevity and conformation traits in the Czech Holstein population. Czech J. Anim. Sci. 57:125-136.

Zavadilová, L., and V. Zink. 2013. Genetic relationship of functional longevity with female fertility and milk production traits in Czech Holsteins. Czech J. Anim. Sci. 58:554-565.

Zwald, N. R., K. A. Weigel, Y. M. Chang, R. D. Welper, and J. S. Clay. 2004a. Genetic selection for health traits using producerrecorded data. I. Incidence rates, heritability estimates, and sire breeding values. J. Dairy Sci. 87:4287-4294. https://doi.org/10 .3168/jds.S0022-0302(04)73573-0.

Zwald, N. R., K. A. Weigel, Y. M. Chang, R. D. Welper, and J. S. Clay. 2004b. Genetic selection for health traits using producer-recorded data. II. Genetic correlations, disease probabilities, and relationships with existing traits. J. Dairy Sci. 87:4295-4302. https: //doi.org/10.3168/jds.S0022-0302(04)73574-2.

Zwald, N. R., K. A. Weigel, Y. M. Chang, R. D. Welper, and J. S. Clay. 2006. Genetic analysis of clinical mastitis data from onfarm management software using threshold models. J. Dairy Sci. 89:330-336. https://doi.org/10.3168/jds.S0022-0302(06)72098-7.

\section{ORCIDS}

S. König @ https://orcid.org/0000-0002-1716-2511 